\title{
8
}
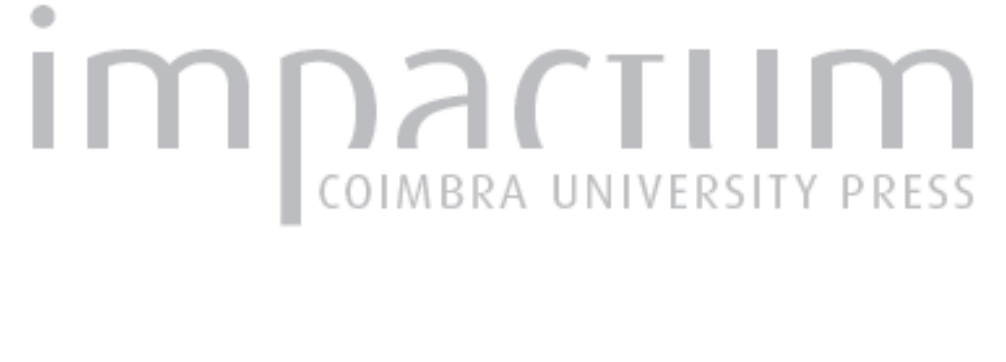

\section{A valorização de monumentos megalíticos como meio de dinamização local}

Autor(es): $\quad$ Carvalho, Pedro Sobral de; Gomes, Luís Filipe Coutinho

Publicado por: Faculdade de Letras da Universidade de Coimbra

URL persistente:

URI:http://hdl.handle.net/10316.2/37719

DOI:

DOI:http://dx.doi.org/10.14195/1647-8657_45_2

Accessed : $\quad$ 26-Apr-2023 13:20:23

A navegação consulta e descarregamento dos títulos inseridos nas Bibliotecas Digitais UC Digitalis, UC Pombalina e UC Impactum, pressupõem a aceitação plena e sem reservas dos Termos e Condições de Uso destas Bibliotecas Digitais, disponíveis em https://digitalis.uc.pt/pt-pt/termos.

Conforme exposto nos referidos Termos e Condições de Uso, o descarregamento de títulos de acesso restrito requer uma licença válida de autorização devendo o utilizador aceder ao(s) documento(s) a partir de um endereço de IP da instituição detentora da supramencionada licença.

Ao utilizador é apenas permitido o descarregamento para uso pessoal, pelo que o emprego do(s) título(s) descarregado(s) para outro fim, designadamente comercial, carece de autorização do respetivo autor ou editor da obra.

Na medida em que todas as obras da UC Digitalis se encontram protegidas pelo Código do Direito de Autor e Direitos Conexos e demais legislação aplicável, toda a cópia, parcial ou total, deste documento, nos casos em que é legalmente admitida, deverá conter ou fazer-se acompanhar por este aviso.

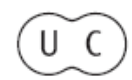




\section{CONIMBRIGA}

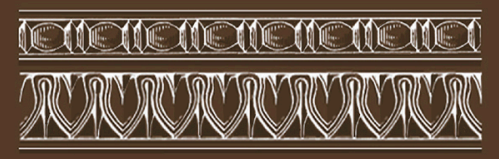

INSTITUTO DE ARQUEOLOGIA

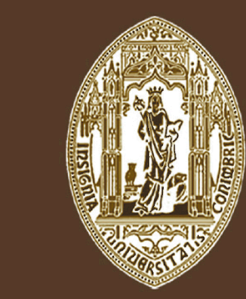

VOLUME XLV - 2006

FACULDADE DE LETRAS UNIVERSIDADE DE COIMBRA 


\author{
Pedro Sobral de Carvalho \\ Luís Filipe Coutinho Gomes \\ Arqueohoje - Conservação e Restauro do Património Monumental, Lda.
}

\title{
A VALORIZAÇÃO DE MONUMENTOS MEGALÍTICOS COMO MEIO DE DINAMIZAÇÃO LOCAL \\ "Conimbriga" XLV (2006) p. 25-32
}

SumÁrio: Neste texto discutem-se ideias e ideais, propostas e argumentos, teorias e hipóteses sobre o como e o porquê da valorização de sítios arqueológicos partindo do exemplo concreto da recuperação de monumentos megalíticos.

Ao longo dos últimos dez anos, a Arqueohoje tem investido na valorização patrimonial com especial incidência em monumentos megalíticos, aprendendo a reconhecer os pontos fortes e fracos deste género de acção. A reflexão dos pressupostos inerentes a este tipo de trabalho faz com que tenhamos consciência de melhores e menos conseguidos trabalhos, mas traz-nos também a certeza que a aprendizagem contínua se reflecte na melhoria dos resultados.

ABSTRACT: In this passage ideas and ideals, proposals and arguments, theories and hypotheses are discussed to know how and why it is important the valuation of archaeological places taking the recovery of megalithic monuments into account.

The Arqueohoje has been investing in the patrimonial valuation for the last ten years with a special incidence in megalithic monuments, and this way it has learned to acknowledge the strong and weak points of this kind of action. The reflection of the inherent presuppositions of this sort of work not only makes us be aware of the best and worst works, but also be certain that the continuous learning reflects itself in better results. 
(Página deixada propositadamente em branco) 


\section{A VALORIZAÇÃO DE MONUMENTOS MEGALÍTICOS COMO MEIO DE DINAMIZAÇÃO LOCAL}

\section{Estudar o quê? Valorizar para quê? Divulgar para quem?}

Os últimos anos do séc. XX trouxeram alguns ventos, ainda que amenos, de mudança nas mentalidades sobre o papel que o Património e as suas diversas vertentes podem representar no contexto social e económico do País.

Sendo o nosso discurso bastante apriorístico e despretensioso, reflecte no entanto alguma experiência no contacto com alguns agentes responsáveis pela defesa, valorização e divulgação do Património.

A primeira e essencial condição para se iniciar um discurso com qualquer interlocutor sobre o Património, seja ele histórico, arqueológico ou natural, é a sensibilidade. Parece ser um termo inócuo, mas reúne em si mesmo a capacidade de continuar ou interromper uma conversa sobre este tema tão abrangente.

Efectivamente, o nosso ouvinte, seja ele um autarca, um professor ou um aluno, tem que estar receptivo ao discurso sobre o Património como factor de progresso intelectual e/ou económico. Quando existe essa simbiose entre emissor, mensagem e receptor, o discurso flui e conseguem-se atingir os objectivos propostos. Caso contrário, o discurso implode e o projecto, a ideia, a proposta cai por terra.

A Arqueohoje, mercê da formação específica e experiência profissional dos seus quadros técnicos superiores, tem vindo a dedicar especial atenção à recuperação e valorização de monumentos megalíticos.

Estes são, como todos sabemos, as primeiras manifestações grandiosas do engenho humano no território português. Trata-se de um património fabuloso que reúne todas as condições necessárias para entusiasmar o público em geral na preservação do Passado. São monumentos que se encontram intimamente ligados às populações locais, 
possuindo uma mística muito própria. São "as casinhas dos mouros", "a cova do ladrão", "a toca do lobo", "a lapa da moura", "o altar da moura", sítios de encontro, de referência, de abrigo, de reunião... Existe todo um imaginário em torno destes monumentos que os torna muito queridos pelas populações próximas. Contudo, raramente existe uma correcta interpretação por parte da comunidade local.

Por isso mesmo, apostamos na criação de estratégias de comunicação com as diversas autarquias assentes numa forte componente didáctica.

O processo inicia-se pela escolha do(s) monumento(s) a valorizar. De seguida, elabora-se um plano de trabalhos arqueológicos, se possível integrado num projecto de estudo mais alargado, normalmente de âmbito regional. Tenta-se, deste modo, resolver questões científicas executando um trabalho rigoroso de escavação, registo e interpretação.

É absolutamente imperioso que os arqueólogos sejam especialistas em megalitismo, pois é um dado adquirido que existem manifestações tumulares muitos heterogéneas que nos tem inclusivamente levado, desde há uns anos, a partilhar o termo "megalitismos" como aquele que melhor exprime a grande diversidade de soluções tumulares dos finais do Neolítico/inícios do Calcolítico. Embora as questões científicas sobre a escavação de um monumento megalítico não sejam o tema deste nosso texto, interessa, no entanto, sublinhar que o trabalho de valorização tem sempre início num trabalho criterioso de índole científica que culmina com a publicação dos resultados em revistas da especialidade.

Segue-se o restauro do monumento. É um trabalho com uma filosofia própria que, acima de tudo, não é estática. Temos a perfeita noção de que algumas das soluções adoptadas na intervenção deste ou daquele monumento foram as possíveis na altura. Hoje existem condições e tecnologias que nos permitem executar um melhor trabalho. Por exemplo, no momento actual é muito mais fácil deslocar uma auto-grua (falamos do interior do País, "do Portugal profundo") do que há dez anos. Foi crucial a melhoria das acessibilidades permitindo uma maior disponibilidade de recursos.

As soluções adoptadas no restauro de um monumento possuem sempre um carácter reversível, pretendendo-se converter a ruína, muita das vezes caótica, numa ruína inteligível e perceptível, aproximando-se do seu aspecto primitivo. Para tal, e a título de exemplo, temos recorrido a várias e diversas soluções na substituição dos esteios vandalizados ou espoliados que variam conforme as condições técnicas, acessibi- 
lidades e orçamentos disponíveis para o trabalho. Assim, na substituição destes, tanto podemos utilizar os muros em alvenaria como os monólitos recolhidos na região, sendo essencial a diferenciação dessa acção. Geralmente, essa informação escrita e visual é prestada nos suportes gráficos que se encontram junto ao monumento (painéis em madeira tratada) e/ou através de desdobráveis ou brochuras patentes em locais apropriados para o efeito, normalmente na autarquia local. Outras considerações de carácter mais técnico-científico podem ser lidas em revistas da especialidade. Agora pretendemos essencialmente discursar sobre as motivações, as fases e as contrariedades deste tipo de trabalhos.

Após a conclusão das acções no campo, avança-se na produção de conteúdos. Estes têm que ser concebidos de um forma correcta motivando à leitura dos vários públicos alvo. Não é uma tarefa fácil, pois por vezes somos levados pelo ímpeto de escrever sobre as questões apaixonantes do megalitismo ou da pré-história. Esquecemo-nos que a percentagem de leitores que se interessam verdadeiramente pelo tema é muitíssimo reduzida. Por outro lado, também não podemos cair no erro de escrever textos elementares, pois estaríamos a colocar de parte um importante conjunto de pessoas que possuem já alguma informação, pretendendo enriquecer o seu conhecimento através da leitura desses textos.

Efectivamente, temos vindo paulatinamente a abandonar aquele género de discurso demasiado elementar, pois cremos que o leitor tem que também fazer algum esforço para se cultivar, representando o texto um ponto de partida numa investigação pessoal. Actualmente, temos vindo igualmente a propor os suportes gráficos alternativos, como sejam os “cadernos do professor". Aí é o sítio correcto para, de uma forma puramente didáctica, se explicar, por exemplo, o que é o monumento, como era construído ou que tipo de oferendas acompanhavam os rituais. É crucial que toda a informação seja complementada com ilustrações exemplificativas, pois uma boa imagem ajuda a interpretar, de uma forma muito mais fácil, o que queremos transmitir.

Uma outra fase importante do processo é a colocação da sinalética. O público só vai visitar os monumentos se estes estiverem devidamente sinalizados, evitando-se a desagradável sensação de se andar perdido no campo à procura de um sítio arqueológico.

Estes são, de uma forma geral, os passos recomendados na valorização de um monumento, sendo essencial demonstrar aos agentes do processo que isto é apenas uma parte do conjunto de acções que devem ser feitas na promoção do Património. 
A mais importante é a concepção de um espaço museológico ou centro interpretativo na sede de concelho ou na freguesia. Os centros interpretativos são instrumentos eficazes na apresentação do Património cultural e natural. É aí que se cativa o público. É a partir daí que o público vai visitar o território, onde se sublinha o sentido de lugar ao visitante e, simultaneamente, se valoriza a própria identidade aos habitantes locais. Os centros interpretativos sustentam-se no conhecimento e na informação, traduzindo-o, "interpretando-o" e fazendo-o chegar ao público de uma forma simples, interessante e original.

A recuperação e valorização de sítios/monumentos requer um programa de manutenção periódica que, na maior parte dos casos, não existe. As autarquias necessitam de criar planos de acção inserindo a comunidade local no projecto. É igualmente uma estratégia de comunicação pois ao conceder responsabilidades acrescidas à sociedade, faz com que esta interaja e se sinta mais unida ao "seu" Património. Referimo-nos às colectividades, aos escuteiros, às escolas e aos programas que as autarquias podem desenvolver com o Instituto da Juventude.

Existe um aumento progressivo de pessoas que experimentam e praticam o turismo cultural. A sociedade actual caracteriza-se por um aumento do tempo do ócio e um crescente interesse por todas as manifestações culturais. A melhoria das acessibilidades e o aparecimento do turismo de massas, ainda que um pouco incipiente no nosso País, tem facilitado o acesso a todo um conjunto de produtos culturais sejam eles monumentos, museus, percursos pedestres, exposições ou feiras.

A valorização do Património é, sem dúvida alguma, um assunto que se discute com mais assiduidade e as suas questões/potencialidades são hoje encaradas com mais objectividade. É absolutamente necessário estarmos atentos e, como agentes responsáveis no processo, executarmos bons projectos de modo a permitir à sociedade em geral encarar o Património como uma inestimável fonte de riqueza cultural e económica. É fundamental tentar chegar até ao maior número possível de pessoas. É urgente incrementar a democratização da cultura.

\section{2. "Study Cases"}

Dólmen da Capela da Senhora do Monte (Fot. 1)

Concelho de Penedono, distrito de Viseu

Anos da acção: 1997 e 1998

Conimbriga, 45 (2006) 25-32 
Dólmen de Sangrino (Fot. 2)

Concelho de Penedono, distrito de Viseu

Anos da acção: 1997 e 1998

Menir do Vale de Maria Pais (Fot. 3)

Concelho de Penedono, distrito de Viseu

Anos da acção: 1997 e 1998

Dólmen de Areita (Fot. 4)

Concelho de S. João da Pesqueira, distrito de Viseu Anos da acção: 1996 a 1998

Dólmen da Fonte Coberta (Fot. 5)

Concelho de Alijó, distrito de Vila Real

Ano da acção: 1997

Anta do Penedo do Com (Fot. 6)

Concelho de Penalva do Castelo, distrito de Viseu Ano da acção: 1998

Orca de Seixas (Fot. 7)

Concelho de Moimenta da Beira, distrito de Viseu Ano da acção: 1999

Dólmen 2 de Chão Redondo (Fot. 8)

Concelho de Sever do Vouga, distrito de Aveiro Ano da acção: 2000

Anta da Capela dos Mouros (Fot. 9)

Concelho de Sever do Vouga, distrito de Aveiro Ano da acção: 2000

Mamoa 1 de Madorras (Fot. 10)

Concelho de Sabrosa, distrito de Vila Real

Ano da acção: 2003

Anta de Pêra do Moço (Fot. 11)

Concelho e distrito da Guarda

Ano da acção: 2001 
Dólmen de Rio Torto (Fot. 12)

Concelho de Gouveia, distrito da Guarda

Anos da acção: 2004 e 2005

Dólmen 2 das Carniçosas (Fot. 13)

Concelho da Figueira da Foz, distrito de Coimbra

Ano da acção: 2003

Anta da Arquinha da Moura (Fot. 14)

Concelho de Tondela, distrito de Viseu

Ano da acção: 2005

\section{BIBLIOGRAFIA}

Morales Miranda, Jorge, 2001, Guia Práctica para la Interpretación del Patrimonio. El arte de acercar el legado natural e cultural al público visitante, 2. ${ }^{a}$ Edição, Consejaría de Cultura, Junta de Andalucía.

MoReno LóPEZ, Gregório, 1998, "Los aspectos gerenciales en el nuevo papel de los museos", Cursos Monográficos sobre el Patrimonio Histórico (8. 1997. Reinosa), Cursos sobre el Patrimonio Histórico 2, Universidad de Cantábria, pp. 49-55.

Moreno-Navarro, Antonio González, 1996, "Patrimonio Arquitectónico: o que el viento no se llevó", Cuadernos, Catalogación del Patrimonio Histórico, Consejaría de Cultura, Junta de Andalucía, Instituto Andaluz del Patrimonio Histórico, pp. 16-28.

SÁNCHEZ GómEZ, Miguel Ángel, 1998, "La difusión del Patrimonio arqueológico: ¿una asignatura pendiente?", Cursos Monográficos sobre el Patrimonio Histórico $\left(8 .^{\circ}\right.$ 1997. Reinosa), Cursos sobre el Patrimonio Histórico 2, Universidad de Cantábria, pp. 145-147. 


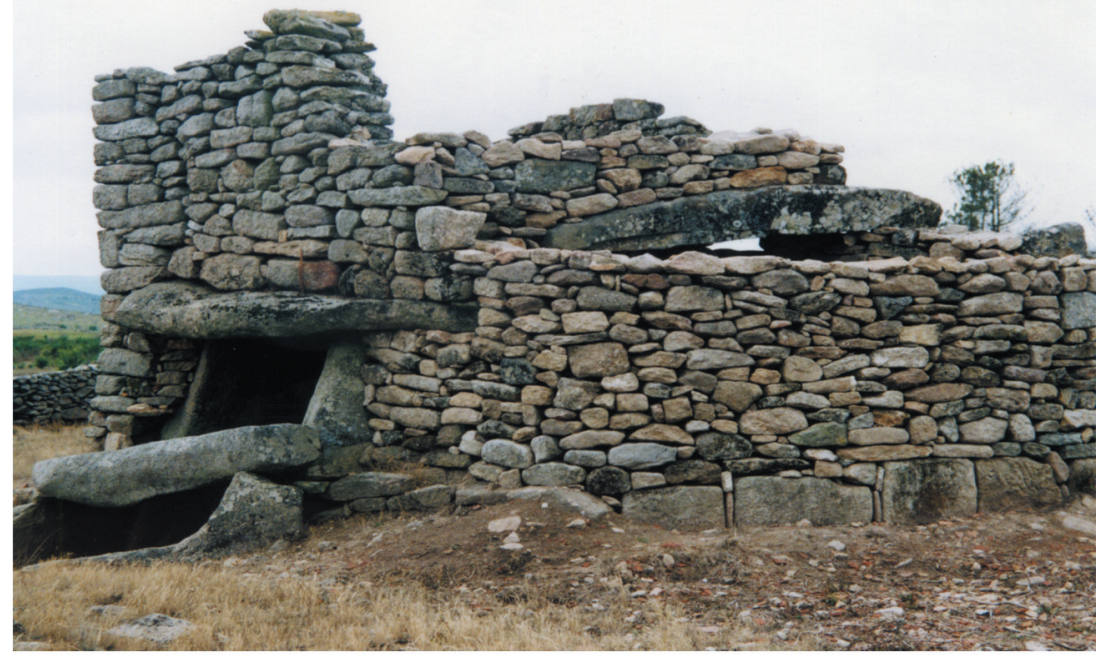

Foтo 1 - Dólmen da Capela da Senhora do Monte (Penedono)

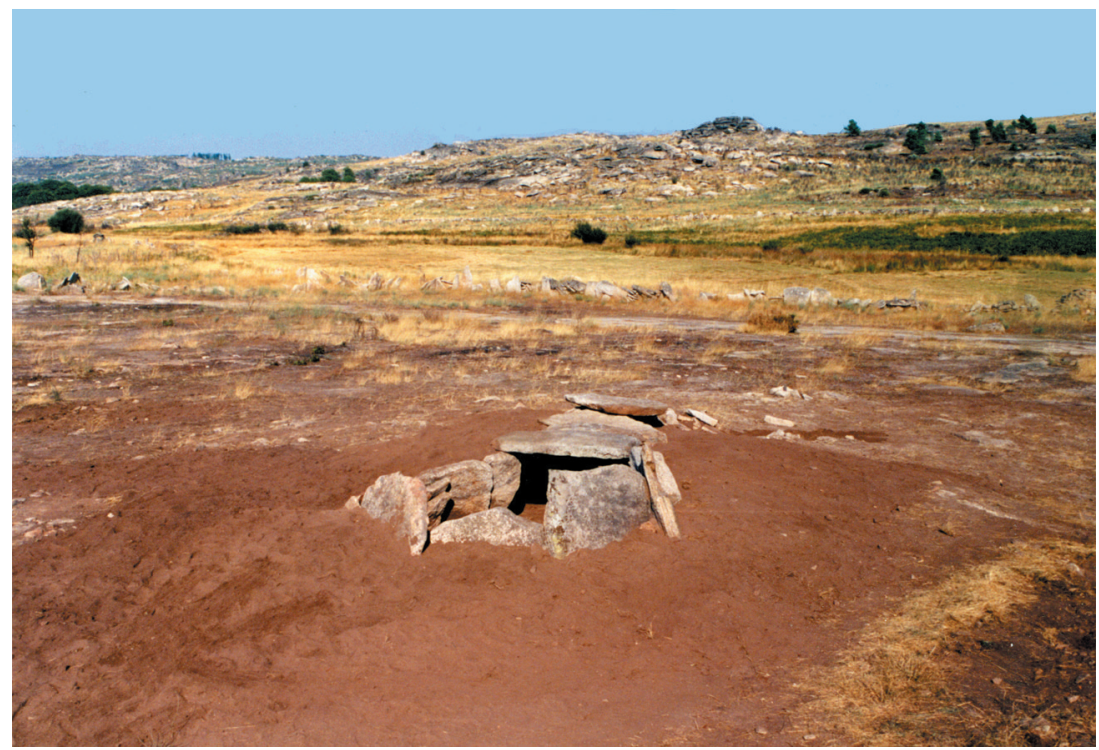

Foto 2 - Dólmen do Sangrino (Penedono) 


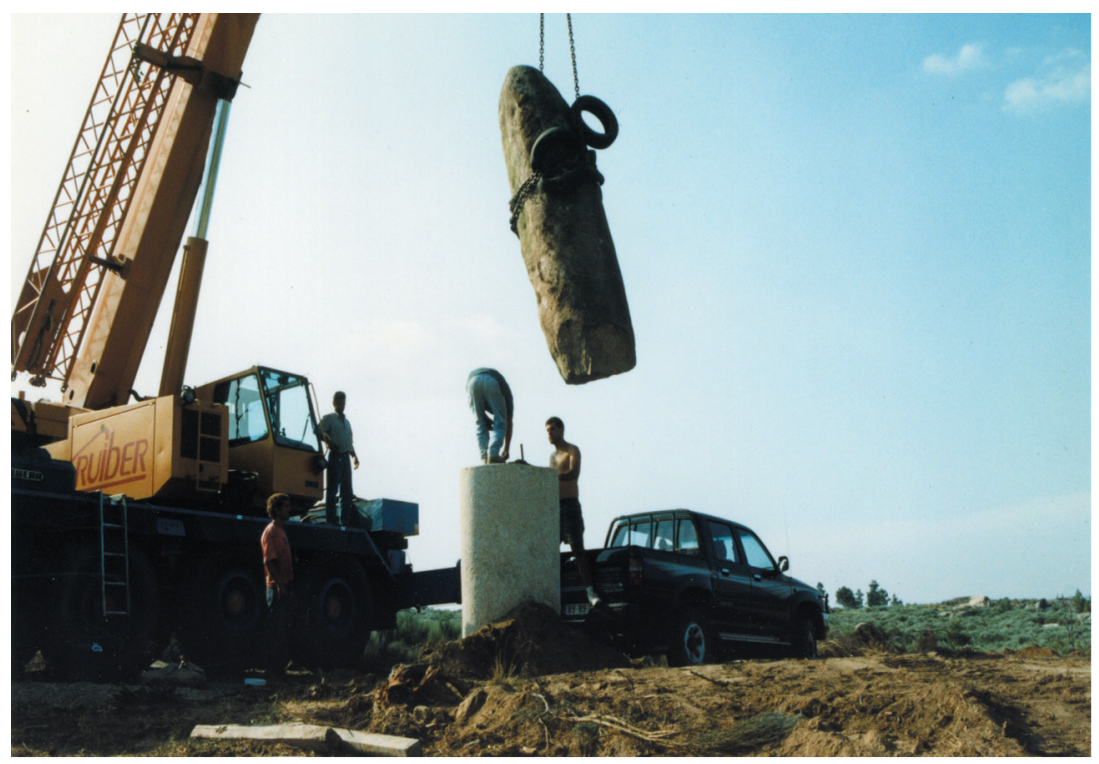

Fото 3 - Menir do Vale de Maria Pais (Penedono)

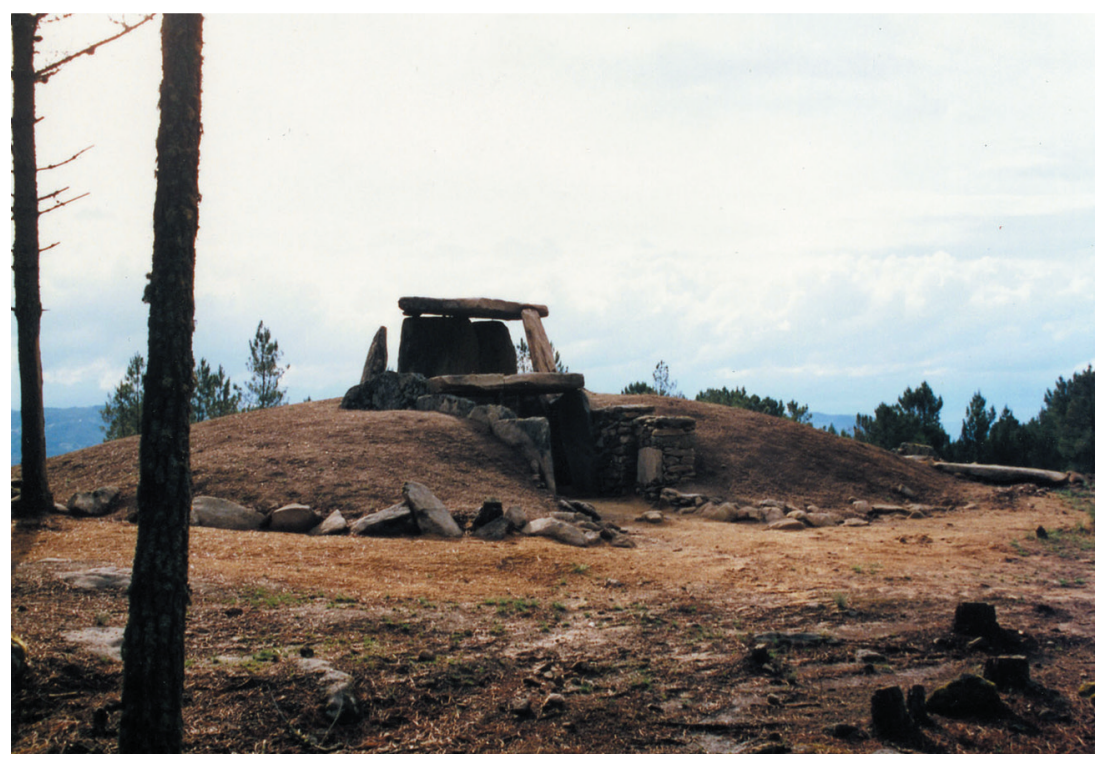

Foто 4 - Dólmen de Areita (S. João da Pesqueira) 


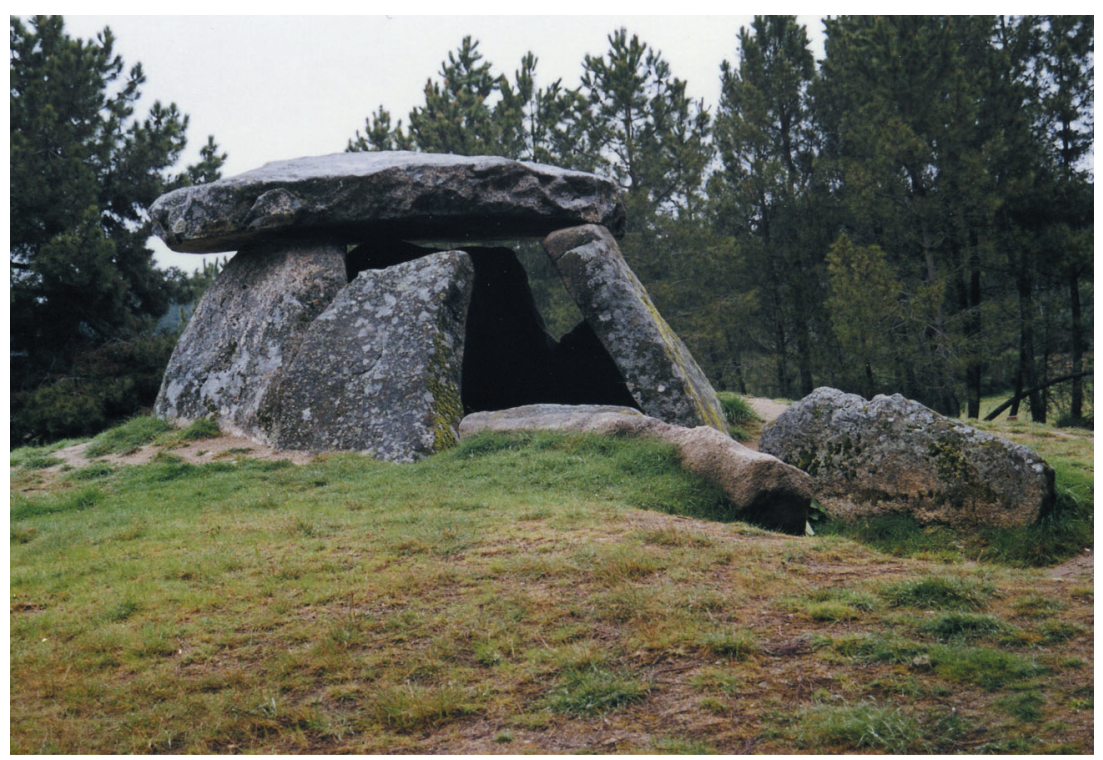

Fото 5 - Dólmen da Fonte Coberta (Alijó)

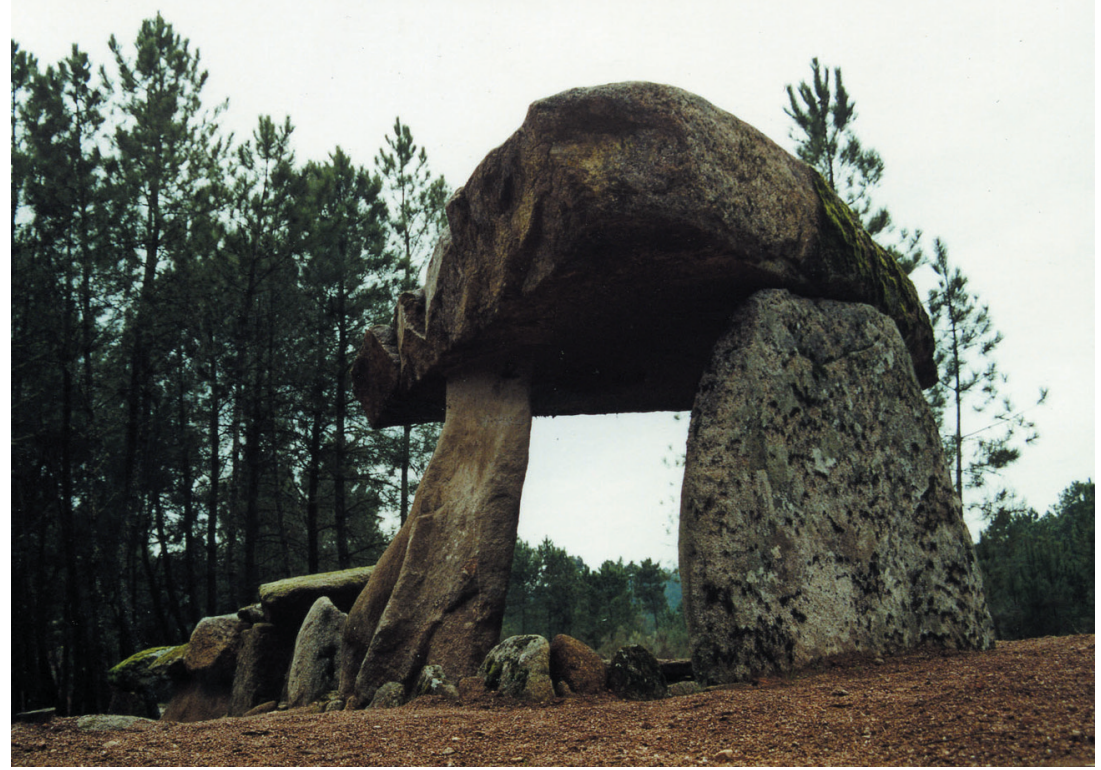

Foto 6 - Anta do Penedo do Com (Penalva do Castelo) 


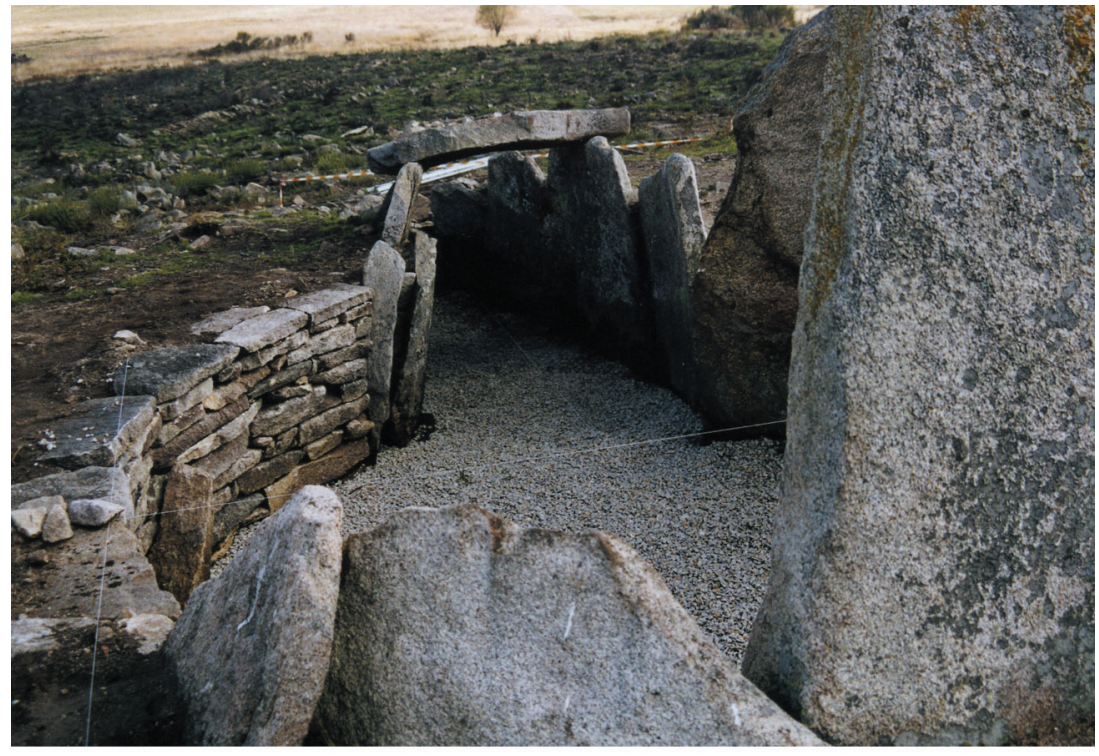

Fото 7 - Orca de Seixas (Moimenta da Beira)

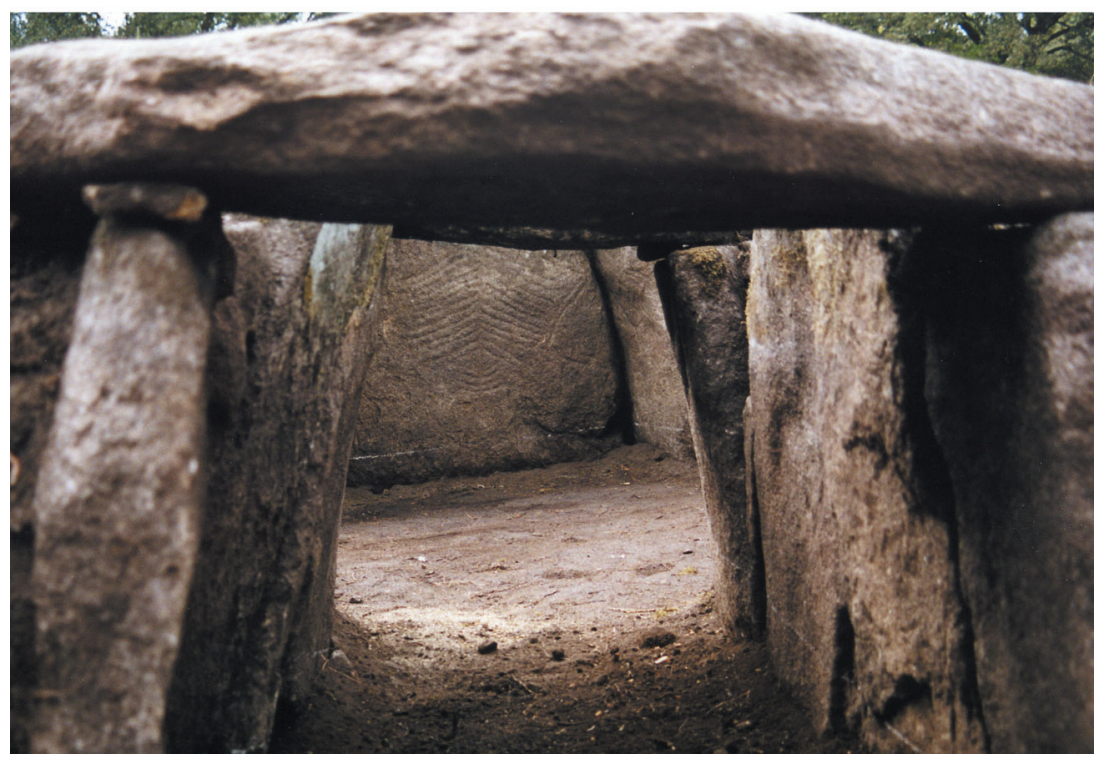

Fото 8 - Dólmen 2 de Chão Redondo (Sever do Vouga) 


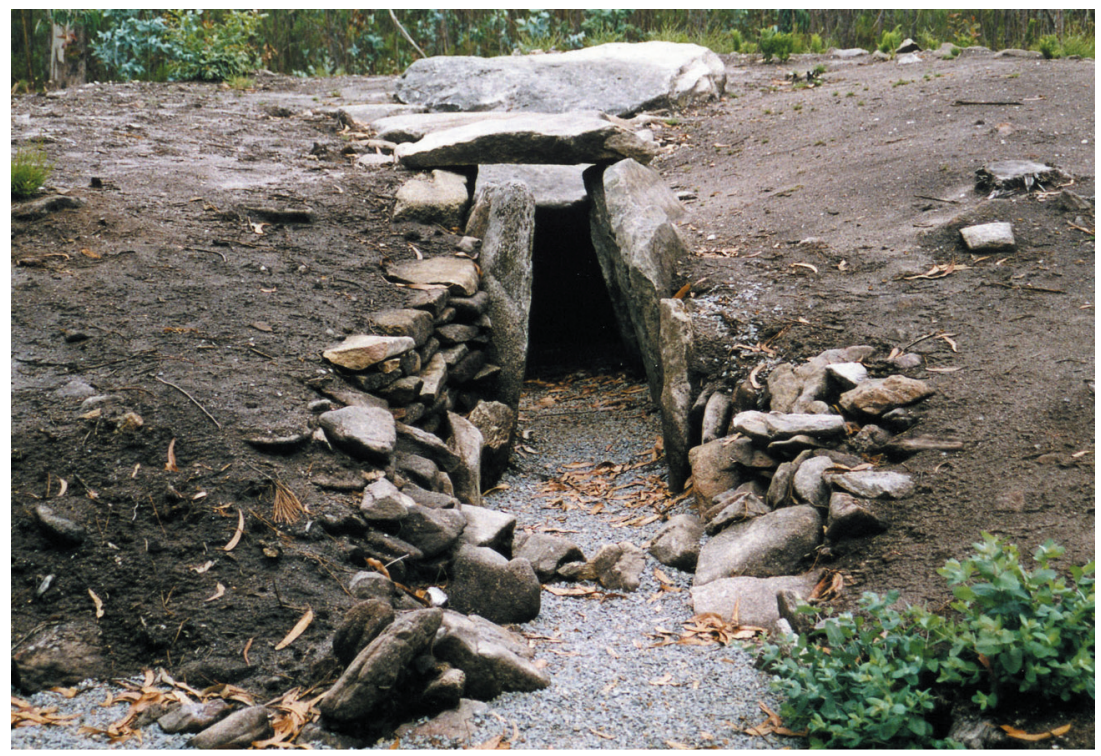

Foто 9 - Anta da Capela dos Mouros (Sever do Vouga)

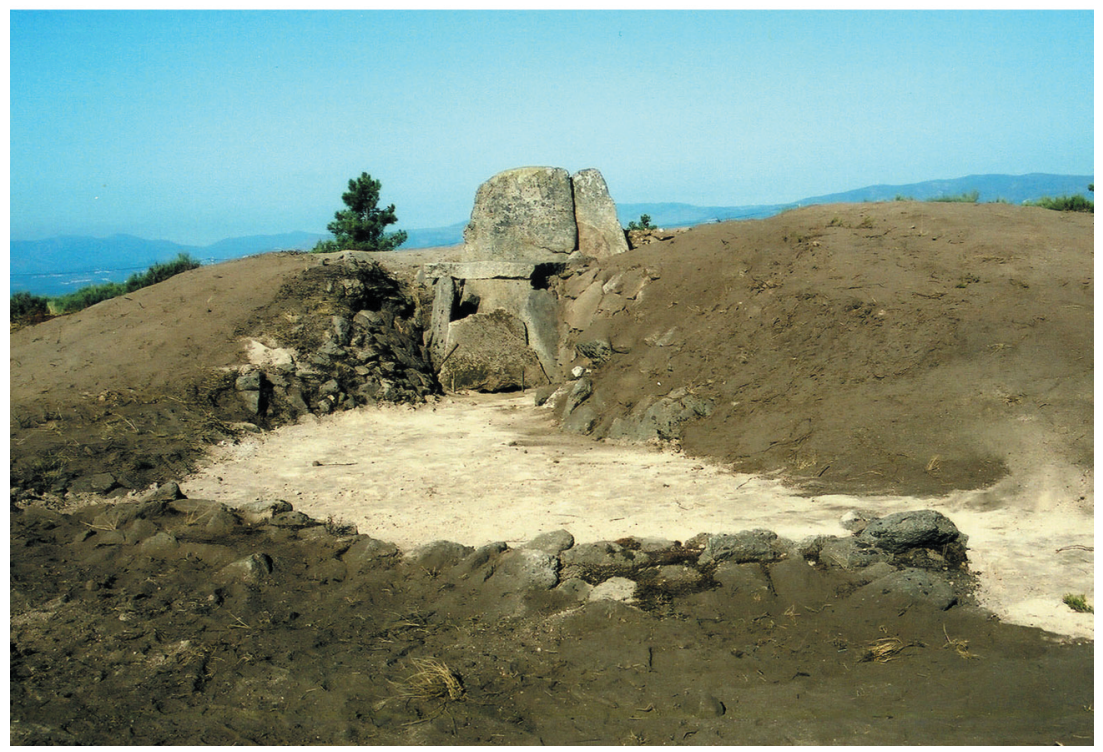

Fото 10 - Mamoa 1 de Madorras (Sabrosa) 


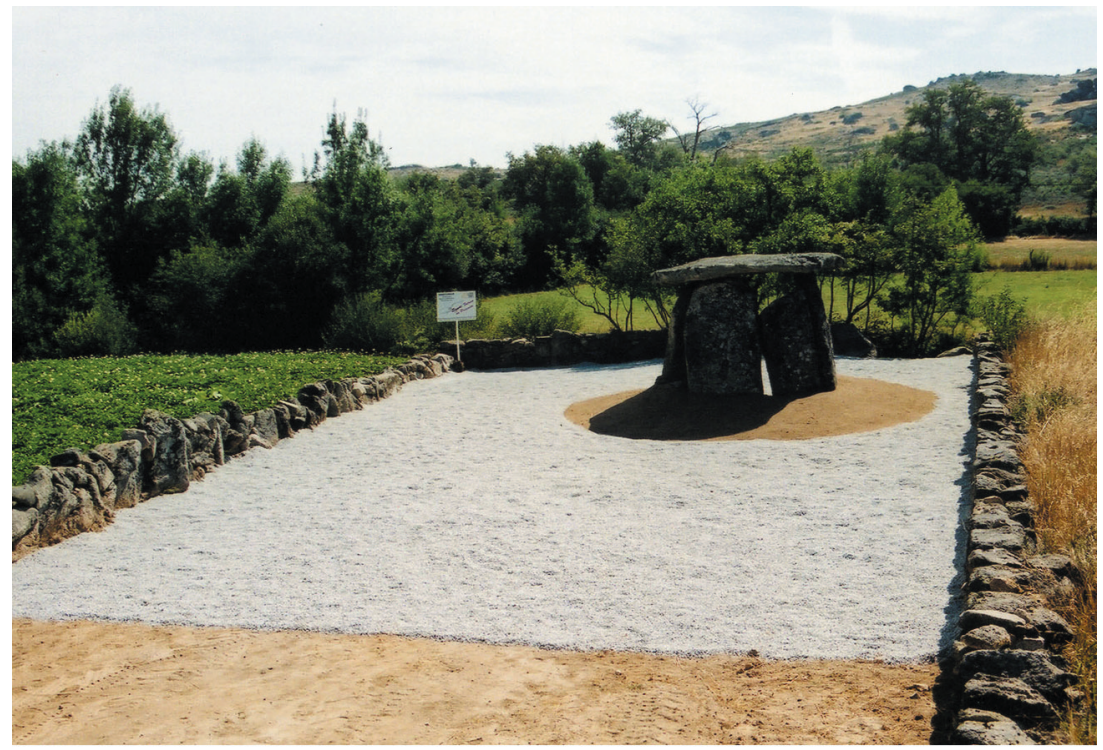

Foto 11 - Anta de Pêra do Moço (Guarda)

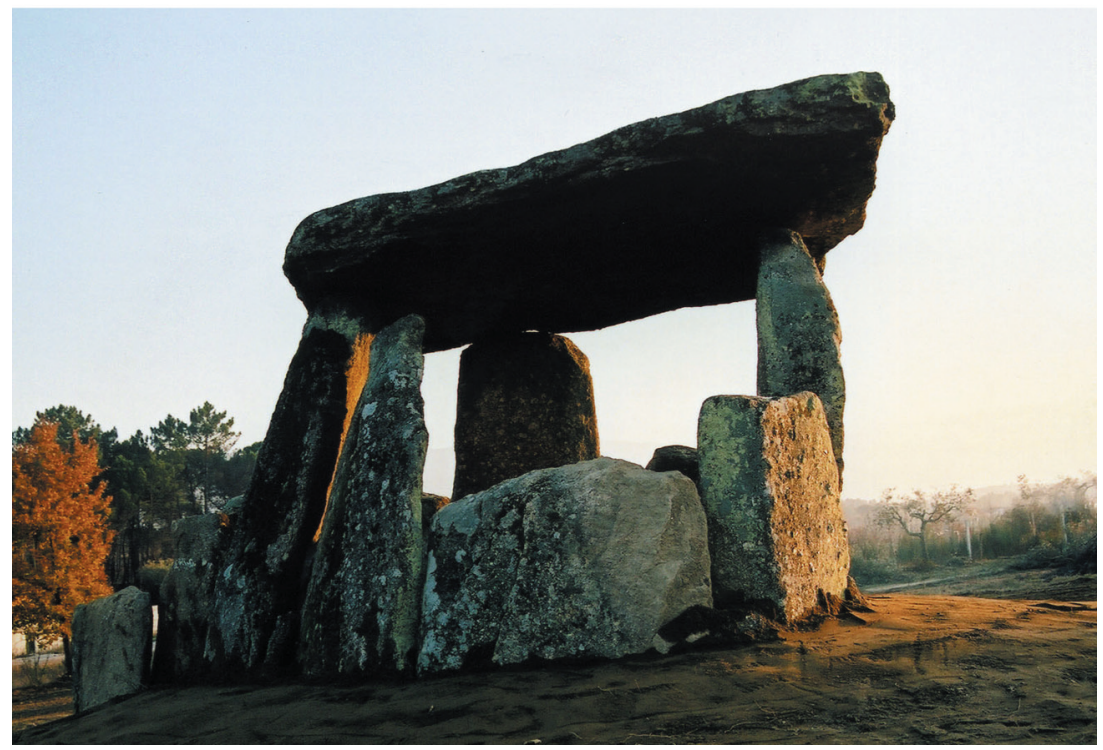

Foто 12 - Dólmen de Rio Torto (Gouveia) 


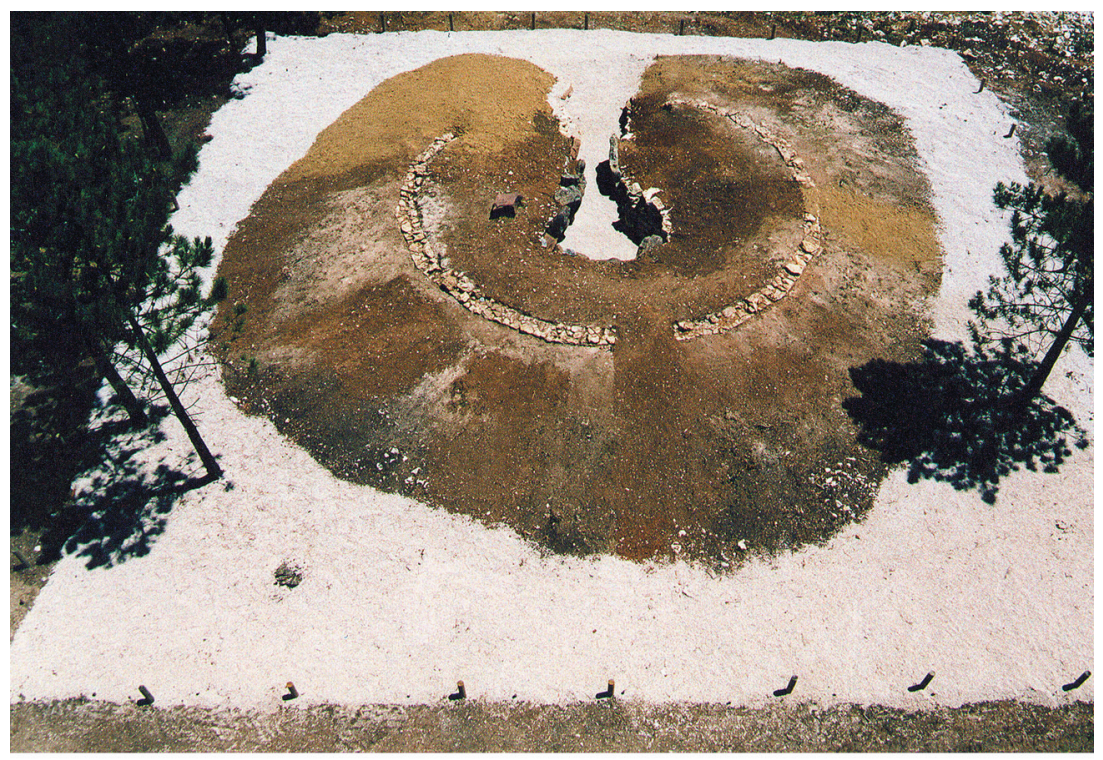

Foтo 13 - Dólmen 2 das Carniçosas (Figueira da Foz)

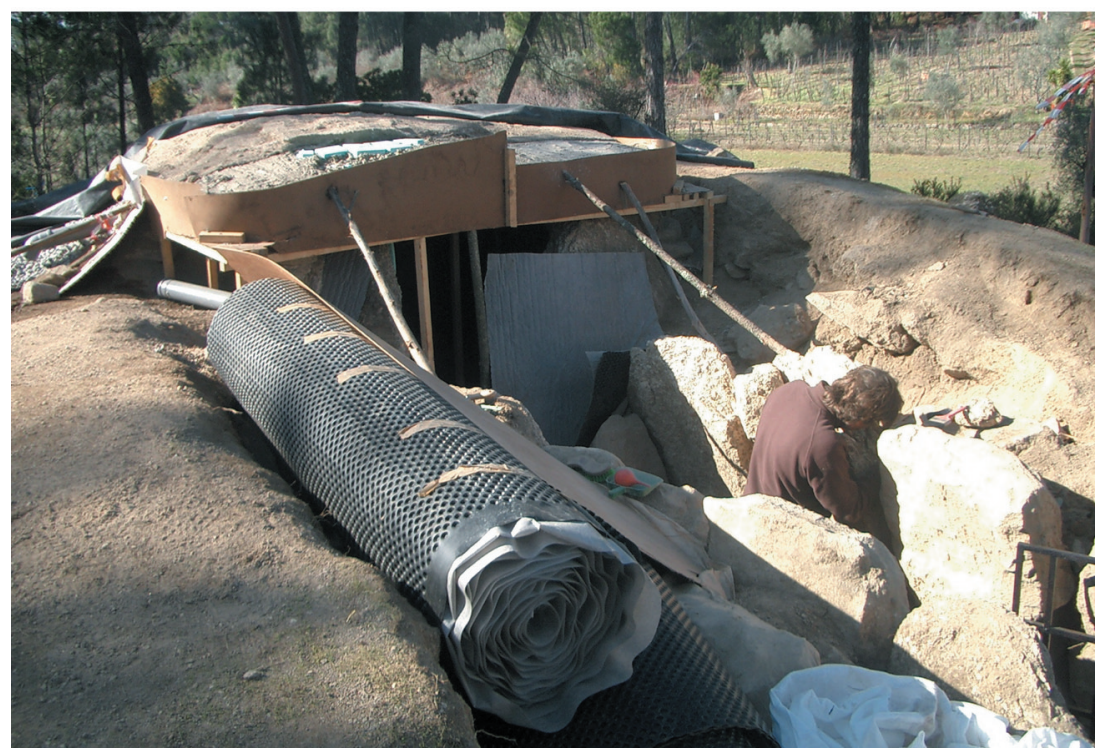

Fото 14 - Anta da Arquinha da Moura (Tondela) 